\title{
Supply chain management en bedrifseconomische implicaties voor deelnemers
}

Dr. Ir. M.J.F. Wouters

\section{Inleiding}

Dit artikel gaat over bedrijfseconomische implicaties van supply chain management (SCM): samenwerking tussen onafhankelijke bedrijven die aan elkaar leveren. Het onderwerp staat de laatste jaren volop in de belangstelling in het vakgebied operations management en er zijn diverse nieuwe, gespecialiseerde tijdschriften verschenen (Supply, Chain Management, SCM Review'). SCM zoals het in de operations management-literatuur wordt beschreven, is gericht op verbetering van een supply chain als geheel. Door een betere coördinatie van activiteiten tussen verschillende bedrijven en het stroomlijnen van processen, wordt beoogd de totake kosten in de supply chain te reduceren en/of de service naar de klant aan het einde van de supply chain te verbeteren. De literatuur beschrijft veetal onderzoek naar operationele besturing van de supply chain gebaseerd op wiskundige modellen, en daarnaast worden effecten van SCM beschreven op grond van case studies. Er zijn nauwelijks brede. empirische studies waarin de effecten van SCM worden onderzocht.

In de literatuur krijgt het raakvlak van management accounting en SCM toenemende aandacht. SCM is een innovatieve vorm van werken en de gevolgen hiervan voor het gebruik en de inrichting van management accounting-instrumenten zijn

Dr. Ir. M.J.F. Wouters is universitair hoofddocent Management Accounting for Operations Manage ment aan de Technische Universiteit Eindhoven. Faculteit Technologie Management. interessant om te onderzoeken (Hopwood, 1996). Zo bespreken Ittner e.a. (1997) dat nieuwe manieren van samenwerken gepaard moeten gaan met een andere manier om leveranciers te selecteren en prestaties te meten. Samenwerking heeft betrekking op relatiespecifieke investeringen, informatieuitwisseling, en het gebruiken van elkaars kennis bij het ontwerpen van processen en producten. Dit moet voor leveranciers gepaard gaan met selectiecriteria die anders zijn dan prijs, vaker overleg met leveranciers, grotere betrokkenheid van leveranciers bij strategische planning, en certificatieprogramma's voor leveranciers. Op grond van surveygegevens, concluderen zij dat bedrijven die intensief samenwerken en dergelijke mechanismen nier gebruiken. minder winst maken dan bedrijven die intensieve samenwerkingsrelaties opbouwen en dergelijke nieuwe mechanismen wél introduceren.

In dit artikel behandelen we de relatie tussen SCM en accounting vanuit een iets ander perspectief. We nemen SCM zoals het in de operations management-literatuur wordt beschreven als uitgangspunt en we bespreken of invoering eventueel wordt belemmerd door bedrijfseconomische implicaties. We gaan ervan uit dat door invoering van SCM het totale economische resultaat van de bedrijven in een supply chain kan verbeteren. Verder nemen we aan dat bedrijven slechts vrijwillig deelnemen en SCM invoeren als ze er ook individueel economisch voordeel van hebben. Er is dan een vertaling nodig van ketenbrede economische voordelen naar economische voordelen voor de deelnemende bedrijven. Potentiële bedrijfseconomische belemmeringen voor de invoering van SCM vloeien voort uit onder andere méér informatie-uitwisseling tussen de schakels in de keten en herverdeling van 
activiteiten, investeringen en beslissingsbevoegdheden. Dit wordt bespoken in paragraaf 2. Dergelijke ingrepen hebben gevolgen voor de bedrijfseconomische belangen van individuele bedrijven in de keten (paragraaf 3 ). In de accountingliteratuur ontstaat aandacht voor de vraag op welke wijze SCM voor alle deelnemers aantrekkelijk is (Narayanan en Raman, 1988: Radhakrishnan en Srinidhi. 1997). We sluiten af met conclusies in paragraaf 4 .

\section{Supply chain management}

Er zijn diverse ontwikkelingen aan te wijzen die hebben geleid tot een grotere noodzaak voor SCM in de praktijk. Klanten verlangen vaak kortere levertijden, meer flexibiliteit, snellere introductie van nieuwe producten en dergelijke. Om hieraan te voldoen moeten de verschillende functies zoals marketing, verkoop. inkoop. productie en distributie beter met elkaar samenwerken (Anderson e.a., 1997).

Een betere samenwerking is niet alleen belangrijk over functionele grenzen, mar ook over geografische grenzen. Vooral in Europa hebben pakweg de laatste 10 jaar veel bedrijven hun activiteiten anders georganiseerd. Veel bedrijven hadden in ieder land in Europa eigen organisaties voor productie, inkoop. marketing en verkoop, en ieder land werd als winstcentrum beoordeeld. Nu zien we een meer centrale aansturing op Europese schaal. Verkoop blijft vaak een locale activiteit. maar de coördinatie en standaardisatie in marketing en produclontwikkeling neemt toe, en activiteiten voor inkoop, productie en distributie zijn vaak gecentraliseerd. Een dergelijke structuur vergt omvangrijke informatiesystemen. Het aantal fabrieken wordt drastisch gereduceerd en de fabrieken worden gespecialiseerd. Ten opzichte van de situatie dat ieder land een groot deel van het pakket zelf produceert, zijn er veel minder fabrieken, en ieder product wordt op een beperkt aantal plaatsen voor heel Europa geproduceerd. Dit leidt tot schaalvoordelen (lagere kosten) en een snellere productinnovatie (Abrahamsson en Brege, 1997). De centrale aansturing van inkoop, productie en distributie op basis van informatie over de totale keten binnen het eigen bedrijf wordt ook vaak beschreven onder de noemer van SCM.
Een betere samenwerking tussen functionele gebieden en schakels van de keten is niet alleen binnen een bedrijf belangrijk, maar ook tussen verschillende bedrijven, omdat hierdoor omvangrijke kostenbesparingen en verbeteringen van service mogelijk zijn. Een steeds verdergaande specialisatie maakt herverdeling van activiteiten over meer partijen noodzakelijk, gecombineerd met het gebruik van nieuwe informatietechnologie. Een onderzoek in de VS heeft laten zien dat in de voedingsmiddelen-supply chain een betere samenwerking op allerlei gebieden kan leiden tot kostenbesparingen van ongeveer $10 \%$ van de omzet, dus tientallen miljarden dollars per jaar (Kurt Salmon, 1993). In deze branche wordt SCM meestal ECR genoemd (zie bijvoorbeeld het special issue van Suppl. Chain Management. Vol. 2, nr. 3).

Supply chain management heeft veel betekenissen en is ook als wetenschappelijk onderzoekterrein nog niet duidelijk afgebakend (New, 1997: Bechtel and Jayaram, 1997; Cooper et al., 1997). Onder meer Davis ( 1993 ), Lee en Billington (1992) en Buzzel en Ortmeyer (1995) geven duidelijke overzichten van wat SCM kan inhouden. Tsay e.a. (1999) wijzen erop dat SCM veel lijkt op multi-echelon voorraadtheorie, maar méér omvat. Multi-echelon voorraadtheorie gaat over de beheersing, timing en hoeveelheden van materiaalstromen. SCM gaat bovendien over verschillende beslissers, contractuele overeenkomsten. uitwisselen van informatie. de inrichting van de supply chain en het ontwerp van producten. In dit artikel beperken we ons tot de operationele samenwerking rond de levering van producten, omdat SCM in deze activiteiten vaak veel verder gevorderd is dan samenwerking bij productontwikkeling. "category management', verkoopacties, en dergelijke (Buzzel en Ortmeyer, 1995).

Meer uitwisseling van informatie, eventueel via EDI, is een belangrijk element van SCM. Belangrijke informatie betreft de actuele verkopen aan het eind van de keten, op grond van kassascanning (electronic point-of-sale-data, EPOS). EPOS-data zijn nodig om automatische bestellingen te genereren en kunnen bovendien worden gebruikt om de kwaliteit van bestellingen te verbeteren: met minder voorraad een betere service (beschikbaarheid van producten) realise- 

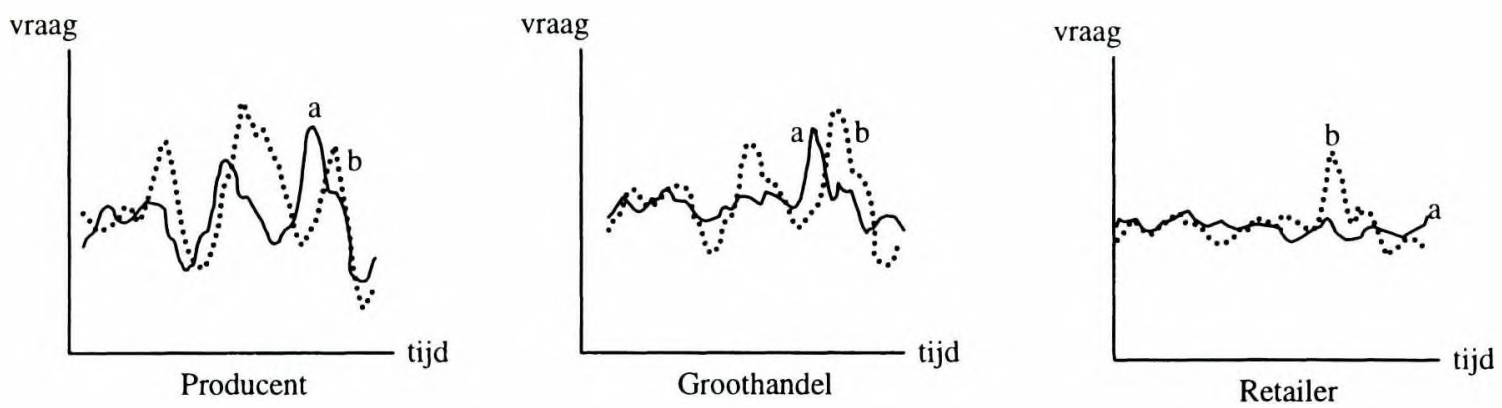

a ontvangen vraag

b uitgaande vraag

Figunr. 1: Opslingereffect in een supply chain: stroomopwarts toenemende onregelmatigheid van de vaug

ren (Bourland e.a., 1996). Normaal hebben leveranciers stroomopwaarts in de keten geen zicht op de vraag van de eindklanten. Men ontvangt bestellingen van de directe klant en alleen die vraag is bekend. Dit leidt tot een enorme toename van de schommeling van de vraag, het zogenaamde 'opslingereffect' (Forrester 1961: Van Aken 1973; Lee e.a. 1997). Het opslingereffect is een versterking van de onregelmatigheid van de vraag. Het betekent dat de vraag die stroomopwaarts wordt doorgegeven (uitgaande bestellingen) onregelmatiger is dan de binnenkomende vraag. Een voorbeeld van dergelijke vraagpatronen is weergegeven in figuur 1. Het opslingereffect kan per schakel in de supply chain worden gemeten door de variatiecoëfficient van de binnenkomende vraag te vergelijken met de variatiecoëfficient van de uitgaande vraag (variatiecoëfficient $=$ spreiding : gemiddelde) . Het effect kan onder meer optreden wanneer de vraag verstoord wordt doorgegeven en partijen stroomopwaarts geen zicht meer hebben op de werkelijke vraag aan het einde van de keten. In die situatie makt iedere schakel in de keten een eigen vraagvoorspelling, alleen afgaand op de vraag van de directvolgende schakel. Een toename van de eindvraag leidt tot een hogere bestelling door de supermarkt (om aan de hogere vraag te voldoen en eventueel om de voorraden te verhogen). De groothandel ziet een hogere bestelling en trekt mogelijk de conclusie dat de vraag toeneemt en verhoogt daarom de bestellingen bij de producent extra. De producent op zijn beurt kan eveneens de indruk krijgen dat de vraag toeneemt en concludeert dat een extra verhoging van de productie nodig is, om aan de vraag te voldoen en te anticiperen op vraagtoe- name. Bij een afname van de vraag van de consument werkt het omgekeerd. Een variatiecoëfficient van de vraag die bij de producent ruim twintig maal zo groot is als de variatiecoëfficient van de klantenvraag is geen uitzondering (Hölmstrom, 1997).

Andere oorzaken voor dergelijke opslingereffecten worden gevormd door bestelhoeveelheden en bestelfrequenties die de vraag verstoord doorgeven (afgerond naar boven of naar beneden), door prijsfluctuaties (waardoor bedrijven extra bestellen als de prijzen laag zijn en minder bestellen als de prijzen hoog zijn) en door tekorten (waardoor bedrijven extra bestellen als ze verwachten dat niet aan de volledige vraag kan worden voldaan).

Informatie-uitwisseling kan helpen om de extra kosten van onnodige, heftige fluctuaties (opslingereffecten) te voorkomen. Wanneer alle bedrijven in een bepaalde supply chain informatie krijgen op grond van EPOS-data van de supermarkt. hebben ze zicht op de echte klantenvraag en kunnen ze hun vraagvoorspellingen baseren op dezelfde, meest actuele vraaggegevens. Ook is het van belang om minimale bestelhoeveelheden en bestelfrequenties aan te passen, zodat vaker en in kleinere hoeveelheden kan worden besteld. Dit wordt op een efficiënte manier mogelijk door de toepassing van EDI (lagere administratieve kosten per order) en door uitbesteding van transport aan bedrijven die vrachten kleiner dan een volle truck toch efficiënt kunnen uitvoeren door combineren'. Stabiele prijzen en duidelijke afspraken kunnen belangrijk zijn, en ook regels voor het delen van tekorten (op basis van gereali- 
seerde omzet in het verdelen in plaats van op basis van wie het meeste bestelt).

Behalve informatie over de actuele vraag kan SCM ook gepaard gaan met uitwisseling van informatie over de verwachte vraag. Bijvoorbeeld, in de modegevoelige kledingbranche kunnen fabrikanten en winkelketens gezamenlijk een vraagvoorspelling maken op grond van de eerste verkoopcijfers vroeg in het seizoen. Vervolgens kan de productie daarop worden aangepast. Dit leidt tot een betere aansluiting van productie op de vrag van consumenten (minder gemiste verkopen en minder afprijzen) in vergelijking met de situatie dat winkelketens de volledige bestellingen moeten doen voorafgaand aan het seizoen (Fisher e.a., 1994). Het is ook mogelijk dat partijen eerst informatie uitwisselen over de verwachte vraag op een hoger aggregatieniveau (bijvoorbeeld aantallen per productgroep. in plaats van per product), terwijl de bestellingen later op detaihniveau worden doorgegeven. De geaggregeerde, vroegtijdige informatie kan bijvoorbeeld worden gebruikı om een betere beslissing te nemen over de hoeveelheid beschikbare capaciteit of over de hoeveelheid in te kopen componenten (als deze een hoge prijs hebben en een lange lever(ijd). Zie bijvoorbeeld De Kok (1990), Wormann (1994), Van der Vlist e.a. (1998).

In sommige supply chains is vraaginformatie beschikbaar die niet wordt gebruikt. In bouwprojecten bijvoorbeeld is de materiaalbehoefte gedetailleerd bekend op grond van het ontwerp. De planning van het bouwproject beval informatie over de timing van de materiaalbehoefte. Toch wordt deze informatie lang niet altijd gebruikt in de supply chain. Voor technische installaties. bijvoorbeeld. is het vrij gebruikelijk dat veel materialen vlak van tevoren bij de groothandel worden besteld. Van Donselaar e.a. (1999) analyseren de voordelen van het eerder doorgeven van informatic over de materialbehoefte, op een moment dat deze informatie echter nog niet helemaal zeker is. Deze informatie kan worden gebruikt on voorraden te verlagen, maar kan bij te grote onbetrouwbaarheid ook leiden tot hogere voorraden in de keten.

SCM kan nog verder gaan. De uitwisseling van informatie maakt het ook mogelijk om hes/issingshevergdheden anders te verdelen. Uitwisseling van EPOS-data, zoals hiervoor besproken, heeft potentieel diverse voordelen, maar nog steeds gaat men ervan uit dat de afnemer zélf bestellingen plaatst. Een stap verder is, om niet meer zelf te bestellen, maar de leverancier de verantwoordelijkheid te geven de voorraad op peil te houden en te laten beslissen over voorraadaanvullingen. Dit wordt vaak aangeduid met 'Vendor Managed Inventory' (VMI). Daartoe krijgt de leverancier, naast EPOS-data, ook informatie over de voorraad bij de afnemer. De leverancier besluit de voorraad bij de afnemer an te vullen en stuurt informatie alan de afnemer over geplande leveringen. De afnemer plaatst dus geen bestellingen meer. VMI kan voordelen opleveren voor de keten. als de producent betere informatie heeft over de totale markt voor de eigen producten. of als de producent zo de aanlevering beter kan afstemmen op de planning van productie en transport. Een tussenvorm is dat de producent een alubevolen bestelling maakt, dic de afnemer eerst nog moet goedkeuren. Een voorbeeld van VMI wordt gegeven door Holnström (1998) en door Wouters (1999).

SCM kan ook gepaard gaan met herverdelen ran activiteiten (Cavatino 1991). Dit kan bijvoorbeeld betrekking hebben op de vraag welke partij in de keten het beste voorraad kan aanhouden. Dit is het terrein van de multi-echelon voorraadtheorie. Herverdeling van activiteiten kan ook te maken hebben met specialisatie. Anderson e.a. (1997) en Wouters e.a. (1999) beschrijven dat SCM in toenemende mate ertoe zal leiden, dat verschillende activiteiten worden uitgevoerd door die partijen in de keten die daarvoor het meest toegerust zijn. Sommige bedrijven zullen zich bijvoorbeeld meer specialiseren in verkopen (onderhandelen, orders afhandelen), terwijl andere bedrijven meer gespecialiseerd zijn in productie of distributie, after-sales service, opleiding, et cetera. In plaats dat één bedrijf alle functies uitoefent, zal er steeds meer sprake zijn van gespecialiseerde bedrijven die samenwerken. Zo kan een bedrijf verschillende supply chains bedienen. De gespecialiseerde functies worden 'een vak apart': een nichemarkt voor de afzonderlijke bedrijven.

Een voorbeeld van herverdeling van activiteiten in de supply chain heeft betrekking op value 
added logistics'. Dit betekent dat een bedrijf dat transport en opslag verzorgt, nog andere activiteiten gaat uitvoeren. Denk daarbij bijvoorbeeld aan het assembleren van pc's volgens specificaties van de klant, het land-specifiek maken van pc's, het installeren van kopieerapparaten bij klanten, een universeel product van een merk voorzien (private label of eigen merk van de producent), et cetera. We komen dan vaak de term 'logistieke dienstverlener' tegen. Deze activiteiten hebben een hogere toegevoegde waarde dan alleen transport en opslag, en bieden voor de logistieke dienstverlener een mogelijkheid zich te onderscheiden (zie bijvoorbeeld Berglund e.a., 1999).

Het voorbeeld van "value added logistics" brengt ons bij het onderwerp 'postponement'. Dit betekent dat producten zo lang mogelijk in de supply chain universeel toepasbaar worden gehouden. Het specifiek maken van het product voor bijvoorbeeld een klant of groep van klanten wordt uitgesteld (Feitzinger en Lee, 1997; Van Hoek, 1998). Een eenvoudig voorbeeld is dat verf pas in de winkel, nadat de klant een bestelling heeft gedaan, de gevraagde kleur krijgt. Het zou onrealistisch veel voorraad vergen om alle kleuren direct te kunnen leveren. Een ander voorbeeld is dat pc's in het Verre Oosten worden gefabriceerd en dat pas in Europa het toetsenbord en andere land-specifieke onderdelen worden toegevoegd, bijvoorbeeld door een logistieke dienstverlener. Ook kopieerapparaten kunnen zodanig worden ontworpen, dat specifieke functies er laat in de supply chain met losse modules aan worden toegevoegd.

We concluderen dat SCM veelal gepaard gaat met veranderingen ten aanzien van de verdeling van activiteiten (en kosten), bedrijfssmiddelen (en investeringen), informatie en beslissingsbevoegdheden. In de volgende paragraaf bespreken we de bedrijfseconomische gevolgen van SCM voor de deelnemende bedrijven.

\section{Bedrijfseconomische implicaties}

In paragraaf 3.1 bespreken we de gevolgen van SCM voor systemen voor economische analyse. Deze systemen dienen een analyse van kosten en opbrengsten in de supply chain mogelijk te maken. Dergelijke analyses kunnen helpen om de supply chain anders in te richten. Deze herinrichting zal veelal gepaard gaan met investeringen en desinvesteringen. We bespreken in paragraaf 3.1 tevens een aantal bedrijfseconomische implicaties die kunnen leiden tot belemmeringen voor de invoering van SCM. Verder bespreken we in paragraaf 3.2 dat SCM zal kunnen leiden tot veranderingen in de systemen voor prestatiemeting. Tot slot bespreken we in paragraaf 3.3 een aantal bedrijfseconomische implicaties van de toenemende informatie-uitwisseling, die veelal is vereist bij invoering van SCM.

\section{I Kostensistemen en investeringen}

In de fase van productontwikkeling zal SCM vaak leiden tot systemen voor 'target costing' en andere vormen van bedrijfseconomische informatie-uitwisseling (Cooper en Yoshikawa, 1994). Bedrijven gebruiken dergelijke systemen om tijdens de ontwikkeling te overleggen over de toegestane en de verwachte kosten van producten. ondat de verwachte kosten in dat stadium nog het meest kunnen worden beïnvloed door aanpassing van het productontwerp.

SCM kan ook worden ondersteund door nieuwe systemen voor kostenanalyse, die de nadruk leggen op kosten van activiteiten. Een goed inzicht in de kosten van activiteiten kan helpen om de inrichting van de supply chain te verbeteren. Zo bespreken Carr en Ittner (1992), Roodhooft en Konings (1996) en Ellram (1995) 'total cost of ownership'. Dit betekent dat een bedrijf alle kosten die gepaard gaan met de verwerving van resources zoveel mogelijk in kaart brengt. Voorbeelden in deze literatuur zijn er vaak op gericht om te laten zien dat onderdelen die de laagste inkoopprijs hebben, voor de organisatie toch hogere kosten kunnen meebrengen dan duurdere onderdelen, omdat de goedkopere onderdelen zorgen voor extra kosten van keuring, storing, en dergelijke. Veel verder gaat het concept dat Lalonde en Pohlen (1996) en Shank en Govindarajan (1992) bespreken: "value chain analysis". Een belangrijk kenmerk daarvan is, dat een bedrijf niet alleen de kosten van de eigen activiteiten in de supply chain zou moeten analyseren, maar dat bedrijven door samenwerking de kosten over een veel groter deel van de keten kunnen analyseren. Een dergelijke analyse van kosten in de keten kan helpen verbetermogelijkheden, zoals in de vorige paragraaf besproken, 
te ontwikkelen. Er zou bijvoorbeeld kunnen blijken dat bepaalde bedrijven een activiteit efficiënter kunnen uitvoeren dan andere en dat verplaatsen van activiteiten leidt tot lagere totale kosten voor de supply chain. We bespreken in deze paragraaf diverse economische belemmeringen voor bedrijven om te streven naar SCMverbeteringen: verschillende financieringskosten, de implementatiekosten van voorraadverlaging, relatie-specilieke investeringen, voordelen voor concurrenten.

\subsubsection{Herverdeling activiteiten. kosten en investeringen}

SCM gaat vaak gepaard met herverdeling van activiteiten (dus kosten) en bedrijfsmiddelen (investeringen). Een kostenbesparing of omzetverhoging zal vaak bij een andere partij optreden dan degene die extra kosten heeft of extra investeringen moet doen, zoals bijvoorbeeld blijkt uit een onderzoek van A.T. Kearney (Burnes en New, 1997). Omdat we ervan uitgaan dat er in totaal een verbetering optreedt, zullen de economische voordelen hiervan moeten worden herverdeeld, bijvoorbeeld doordat de partijen die extra investeren en/of kosten maken een hogere prijs krijgen (en/of een lagere prijs betalen). Toch zal prijsaanpassing niet altijd tot bevredigende oplossingen kunnen leiden, want prijsaanpassing kan weliswaar de extra kosten van een bedrijf compenseren. maar de eventueel vereiste investeringen kunnen een knelpunt blijven vormen. Er is creativiteit voor nodig om kosten, opbrengsten en investeringen te herverdelen in de keten.

Eén mogelijkheid is. dat een bedrijf investeringen doet en deze plaatst bij een ander bedrijf dat ermee moet werken. Zo worden investeringen herverdeeld. Stel bijvoorbeeld dat een producent en een logistieke dienstverlener de totale voorraad kumnen verlagen door deze bij de logistieke dienstverlener te plaatsen. Om te voorkomen dat deze partij moet investeren in deze voorraad, kan de voorrad eigendom blijven van de producent. Een ander voorbeeld is dat een bedrijf gereedschappen of voorraden fysiek bij een leverancier of een klant plaatst, terwijl die gereedschappen of voorraden eigendom blijven van het bedrijf en dus op de eigen balans blijven staan.

Toch zal ook deze herverdeling door middel van prijzen én investeringen niet altijd tot voor alle partijen bevredigende oplossingen leiden. Dit heeft twee oorzaken: bedrijven beogen met SCM onder meer hun investeringen te reduceren, bijvoorbeeld in voorraden (Burnes en New, 1997). Dat betekent dat de bereidheid bij deze bedrijven om investeringen te herverdelen beperkt is. Een tweede oorzaak kan zijn dat bedrijven in de supply chain verschillende rentabiliteitseisen voor hun investeringen stellen. bijvoorbeeld ondat ze verschillende tinancieringskosten hebben (en afzonderlijke projectfinanciering niet mogelijk is). Indien nu de investering (voor een deel) ten laste komt van het bedrijf met de hogere rentabiliteitseis, dan kan hierdoor een voor alle partijen bevredigende oplossing moeilijk worden. We verwijzen naar Wouters (1999) voor een rekenvoorbeeld.

\subsubsection{Voorracherlaging en vaste kosten}

Er zal niet alleen onderhandeld worden over de herverdeling van kosten. opbrengsten en investeringen, maar ook over wie de eenmalige kosten van invoering van SCM betaalt. Een speciale vorm van invoeringskosten betreft de economische gevolgen van voorraadvermindering in de gehele keten (Buzzel en Ortmeyer, 1995). Veel verbeteringen in SCM zijn gericht op vooraadvermindering, omdat operationele kosten voor opslag, transport, veroudering, et cetera daardoor afnemen en ondat er minder vermogen wordt geënvesteerd in voorraad. Eenmalig heeft vooraadvermindering in de keten gevolgen voor productie of distributie (groothandels, retailers). Voorraadvermindering kan worden gerealiseerd door tijdelijk minder te produceren en/of tijdelijk meer te verkopen.

Minder produceren: de groothandels en retailers kopen tijdelijk minder van de producent en blijven zelf evenveel afzetten. De vooraad wordt afgebouwd. De afzet van de producent, en dus de inkomsten, daalt. Om deze afzetdaling te compenseren en eventueel om eigen voorraad te verminderen, gaat de producent tijdelijk minder produceren en bespaart daarmee op cen deel van de kosten (materiaal, energie, flexibele arbeid, uitbesteding). De vaste kosten voor eigen personeel. afschrijvingen. huisvesting, overhead, et cetera blijven ongewijzigd. De producent bespaart veelal minder kosten dan de gemiste omzet. 


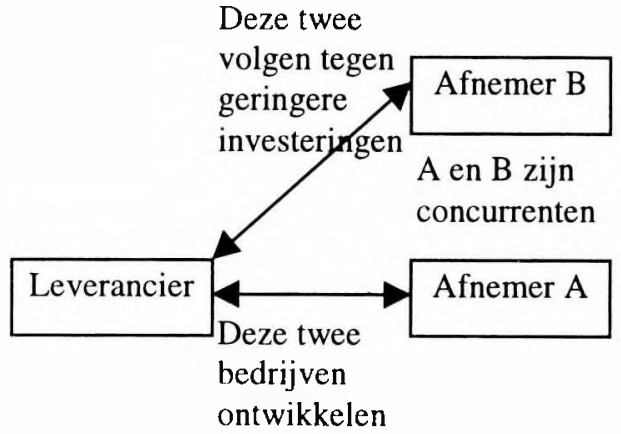

Sithatie A

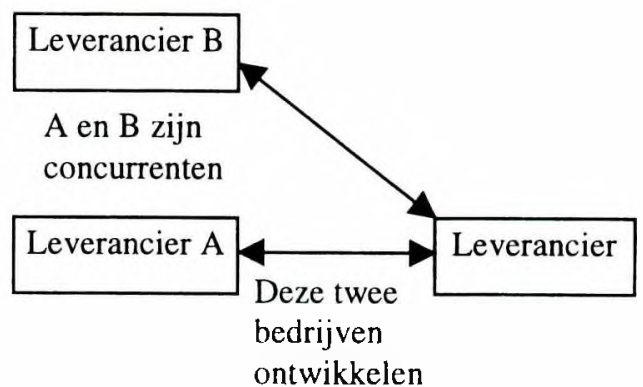

Situctie B

Figutur 2: Twee sithaties waarin investeren in supply chain management vorded oplevert voor concurrenten

Meer verkopen: de groothandels en retailers vergroten de afzet door de prijzen tijdelijk te verlagen. Nu zijn de kosten van voorraadvermindering dus voor rekening van deze partijen.

\section{I.3 Relatie-specifieke investeringen}

Bij de verschuiving van bedrijfsmiddelen en investeringen kan er ook sprake zijn van relatiespecifieke investeringen. Hierdoor ontstaan voor klant en leverancier risico's die met de transactiekostentheorie kunnen worden geanalyseerd (Hobbs, 1996). Zo bespreken Gietzmann (1996) en Gietzmann en Larsen (1998) bijvoorbeeld de Japanse automobielindustrie, waarin leveranciers worden gestimuleerd om te investeren in vaardigheden en kennis, zodat de leveranciers bepaalde activiteiten voor productontwikkeling kunnen overnemen van de opdrachtgever. De leverancier zal echter terughoudend zijn, omdat deze investeringen relatiespecifiek zijn, en daar kan de opdrachtgever misbruik van maken. De leveranciers verlangen een bepaalde beloning en er wordt gebruikgemaakt van een systeem waarin leveranciers kunnen promoveren naar een aantrekkelijkere positie (bijvoorbeeld een groter aandeel leveren van een product, of de meer winstgevende producten mogen leveren). Maar dit systeem is niet in alle omstandigheden toepasbaar, omdat soms de beloning voor de leverancier zodanig hoog dient te zijn, dat daarmee het voordeel voor de opdrachtgever verdwijnt (Gietzmann en Larsen, 1998). Het systeem kan alleen worden toegepast voor leveranciers die bijzonder kundig zijn, dat wil zeggen die de productieacti- viteiten en ontwikkelactiviteiten tegen zeer lage kosten kunnen uitvoeren. De manier waarop de beloning plaatsvindt, moet dus nauwkeurig worden bekeken en zorgvuldig worden geformuleerd, teneinde een verbetering voor de keten daadwerkelijk te kunnen realiseren.

\subsubsection{Innovaties en concurrentievoordelen}

In de onderhandelingen tussen twee samenwerkende partijen, kunnen ook concurrentieoverwegingen een rol spelen (New, 1996). Veel verbeteringen in SCM die twee partijen gezamenlijk ontwikkelen, kunnen later ook in andere samenwerkingsrelaties gebruikt worden en eventueel tegen lagere kosten. Stel dat twee partijen als eerste in een branche samenwerken om EDI in te voeren en daarvoor allerlei problemen oplossen (zoals de definitie van EDI-berichten, problemen in artikelcodering en voorraadregistratie). Volgende EDI implementaties in de branche kunnen dan waarschijnlijk sneller en goedkoper.

Zoals weergegeven in figuur 2 , kan de leverancier later dezelfde verbetering doorvoeren met een andere klant, die een concurrent kan zijn van het bedrijf waarmee de innovatie in eerste instantie is ontwikkeld. Evenzo kan de afnemer later dezelfde verbetering doorvoeren met een andere leverancier, die een concurrent kan zijn van de leverancier waarmee de innovatie is ontwikkeld. Stel nu dat de winst bij een tweede implementatie groter is dan bij de eerste implementatie, omdat de kosten geringer zijn bij de tweede implementatie. Hierdoor zou de bereidheid om te investeren 
in supply chain management kunnen afnemen, indien bedrijven niet willen dat hun concurrenten eventueel een groter voordeel hebben.

Als oplossing kan een periode worden afgesproken waarin de innovatie niet verder wordt verspreid. Er zouden zelfs 'royalties' kunnen worden overeengekomen: als een bedrijf de verbetering later met andere partijen invoert, moet de partij waarmee men in eerste instantie deze verbetering heeft ontwikkeld, meedelen in de winst van dergelijke vervolgprojecten. Het komt ook voor, dat bedrijven niet zoveel belang hechten aan mogelijke voordelen voor concurrenten, bijvoorbeeld wanneer men verwacht dat het wel meevalt met de investeringsvoordelen in latere projecten en als men het belangrijk vindt om als eerste nieuwe ontwikkelingen in te voeren om telkens een voorsprong te behouden op concurrenten.

Een geheel andere situatie ontstaat indien een bedrijf twee leveranciers of twee afnemers tegen elkaar uitspeelt, door tegelijk met beide partijen te onderhandelen. Wanneer deze partijen niet van elkaar weten of de ander meedoet, realiseren ze zich dat als de ander meedoet en zij niet, zij een concurrentienadeel oplopen. Op deze basis zou een bedrijf in staat kunnen zijn een supply chainverbetering door te voeren en bovendien zelf een groot deel van de winst te bemachtigen. Een voorbeeld zien we in de Japanse automobielindustrie, waar afnemers met veel macht hebben bedongen dat zij alle informatie krijgen over innovaties die één van hun leveranciers ontwikkelen en dat zij deze innovatie mogen invoeren bij hun andere leveranciers (Cooper en Yoshikawa, 1994). Meedoen in deze regeling betekent dat de leveranciers dus nauwelijks een concurrentievoordeel kunnen behalen ten opzichte van andere leveranciers - hun concurrenten. Maar niet meedoen levert een concurrentienadeel op. Als gevolg van deze afweging krijgt de afnemer het grootste voordeel.

Samenvattend: herinrichting van de supply chain kan worden ondersteund door een analyse van economische gevolgen in de gehele keten. Wanneer vervolgens de implementatie van verbetermogelijkheden vereist dat sommige bedrijven investeren, dan zijn er diverse belemmeringen voor het doen van investeringen in
SCM. In hoeverre deze belemmeringen optreden en op welke wijze bedrijven hier oplossingen voor vinden (of niet), is een interessant onderzoeksterrein.

\subsection{SCM en prestatiemeting}

De invoering van SCM gaat naar verwachting niet alleen gepaard met veranderingen in de meting en analyse van kosten, maar ook in die van niet-financiële prestaties (Beamon, 1999). Door SCM ontstaat meer interactie en afhankelijkheid tussen bedrijven, waardoor de operationele afspraken veranderen en vaak gedetailleerder worden en de meting van prestaties wordt aangepast aan de gewijzigde afspraken.

Een verandering in prestatiemeting bij invoering van SCM is dat bedrijven de meting op dezelfde manier gaan uitvoeren. Op het moment dat bedrijven gezamenlijk de prestatie van processen in de supply chain proberen te verbeteren, blijkt vaak dat men die prestatie op verschillende manieren meet. Het blijkt dan bijvoorbeeld dat de meting van de leverancier een andere waarde oplevert ten aanzien van de leverbetrouwbaarheid dan de meting van de klant over dezelfde periode en dezelfde transacties. Onderzoek doen naar deze verschillen en op dezelfde manier meten van de prestatie vormen een eerste stap naar een betere samenwerking.

De prestatiemeting (wat wordt gemeten) zal vaak veranderen onder invloed van SCM. SCM gaat gepaard met een nauwkeuriger afstemming van processen, minder voorraad, kortere doorlooptijd, hogere bezettingsgraad et cetera, en daarmee wordt tevens de kwetsbaarheid van processen vergroot. Zo zal een autofabriek die maar voor enkele uren voorraad heeft en die met JIT-leveringen meerdere malen per dag wordt beleverd, erg kwetsbaar zijn voor storingen. Zonder verdere maatregelen kunnen bijvoorbeeld files leiden tot stagnatie in de productie. Er zullen daarom nauwkeurige afspraken moeten worden gemaakt over bijvoorbeeld de tijdstippen van bestellen en leveren, en de meting van de werkelijke prestatie zal evenzeer gedetailleerd zijn.

De prestatiemeting zal ook veranderen als SCM leidt tot nieuwe manieren om processen te besturen, zoals Vendor Managed Inventory. In de 
vorige paragraaf is besproken dat bij VMI de voorraadbesturing van een bepaalde groep items in een bedrijf wordt overgelaten aan de leverancier van die betreffende items. Deze besturing heeft gevolgen voor de prestatiemeting: er wordt gemeten wat de beschikbarkheid is van de producten (hoe vaak men misgrijpt bij het samenstellen van orders). Er is geen meting meer van de leverbetroumbanheid in de gebruikelijke zin van afleveringen ten opzichte van bestellingen er zijn immers geen bestellingen meer.

\subsection{Informatie-uitwisseling en macht}

Partijen die aan elkaar leveren, beschikken over specifieke kemmis. Dat geeft hen een machtspositie ten opzichte van de andere partijen in de keten. Zo heeft de winkelorganisatie kemnis over de vraag van consumenten, niet alleen de gedetailleerde vraag per product, maar ook informatie over wie het product kopen, in combinatie waarmee el cetera, door koppeling van klantenkaart en EPOS-data. Zo heeft de producent informatie over het productieproces, innovaties in de sector, commerciële acties van concurrenten van deze winkelorganisatie, et cetera. Het voordeel van de specifieke informatie wordt afgezwakt wanneer SCM gepaard gaat - en dat gaat het eigenlijk altijd - met toenemende informatieuitwisseling tussen partijen in de keten. De informatie-asymmetrie tussen de partijen wordt verminderd en daarmee verliezen partijen de voordelen die hieraan verbonden kunnen zijn. SCM kan weliswaar leiden tot een grotere winst voor de keten, maar het heeft eventueel ook invloed op de verdeling van die winst.

Een eenvoudig voorbeeld moge het voorgaande verduidelijken. Veronderstel dat een winkelketen en een producent gezamenlijk een promotie van een bepaald product plannen en afspreken dat de winkelketen $f 0,50$ korting krijgt over de extra verkopen (in vergelijking met de gemiddelde vraag 10 weken voor de promotie). Voordat SCM is ingevoerd, weet de producent alleen dat in de betreffende weken de winkelketen 450.000 stuks extra bestelt, en dat de premie dus $f 225.000$ bedraagt. Indien de producent zou beschikken over EPOS-data, dan zou kunnen blijken dat de extra verkoop aan de consument slechts 380.000 stuks bedroeg en dat de winkelketen de voorraad heeft verhoogd, die de laatste weken vóor de promotie sterk was algebouwd. De premie zou dan $f 190.000$ zijn geweest. In dat geval zal de retailer liever geen gedetailleerde informatie over de afzet willen verstrekken, of zal de producent de volgende keer andere afspraken willen maken.

Voor een meer complexe situatie laten Radhakrishnan en Srinidhi (1997) zien dat uitwisseling van EPOS-data nadelig kan uitwerken voor de retailer, omdat daarmee de mogelijkheden voor de retailer komen te vervallen om op grond van de eigen kennis over de vraag, de kosten en de effecten van promotionele activiteiten, een gunstig contract met de producent af te sluiten. Een kleiner deel van een in totaal grotere winst kan ongunstig uitpakken voor een partij, en dit gegeven kan de samenwerking in de weg staan.

Als er meer informatie wordt uitgewisseld is het ook mogelijk om beslissingsbevoegdheden over te hevelen, teneinde de totale keten beter te laten werken. In de vorige paragraaf bespraken we het voorbeeld van VMI. Laten we nu eens kijken hoe dit voor individuele partijen nadelig kan uitwerken in verband met de toegenomen alhankelijkheid. In de oude situatie bestelt een retailer en wordt er gemeten in hoeverre de door de producent toegezegde leveringen daadwerkelijk op tijd en volledig worden geleverd. De producent zal meestal aan meerdere partijen leveren. Indien er tekorten optreden omdat de marktvraag toeneemt of omdat de productiecapaciteit afneemt (bijvoorbeeld door kwaliteitsproblemen), moet de beschikbare productie worden verdeeld over meerdere afnemers. Grote retailers zullen een groot deel krijgen, ondat de producent kosten heeft bij slechte levering (expliciete boetes in contracten, of de dreiging dat de retailer volume verplaatst naar een andere producent). Kleine retailers hebben minder macht en zullen meestal op een andere manier proberen hun aandeel in de toewijzing positief te beïnvloeden: door méér te bestellen dan werkelijk nodig is (overvragen).

In een situatie van VMI bestellen de retailers niet, maar houdt de producent de vraag en de voorraad in de gaten en beslist zelf over aanvulling van de voorraad, zodanig dat de retailer een bepaalde beschikbaarheid heeft van de goederen in het voorraadpunt. Het zal duidelijk zijn dat de invoering van VMI invloed heeft op de afhanke- 
lijkheid en machtspositie van de retailers. Beide retailers worden kwetsbaarder: eerst betekende een slechte service dat de aanvulling van de voorraad niet volgens planning verliep, maar nu betekent een slechte service dat producten ontbreken op het moment dat ze nodig zijn om wit het voorraadpunt te nemen. Voor de grote retailer verandert er niet zoveel, want deze kan zijn macht gebruiken om van voldoende levering verzekerd te zijn. De kleine retailer verliest echter de mogelijkheid om door overvragen zijn aandeel in eventuele tekorten te beïnvloeden. Ofschoon de keten efficiënter kan werken, bestaat de kans dat niet alle partijen akkoord gaan.

Er zijn dus diverse belemmeringen voor bedrijven om de benodigde informatie te delen en beslissingen te (laten) nemen in het belang van de totale supply chain. Er is reeds veel onderzoek gedaan naar de aanpassing van contracten (Tsay e.a., 1999, geven een overzicht van de literatuur). De aanpak is vrijwel steeds om eerst de beste werkwijze voor de gehele keten te bepalen. Vervolgens worden zodanige contracten en prijsstructuren ontworpen, dat alle partijen zullen overgaan op die beste werkwijze. Voordat partijen hiertoe overgaan, zullen ze dus het vertrouwen moeten hebben dat ze erop vooruit gaan. Dat niet alleen de totale 'koek' groter wordt, maar dat hun aandeel in ieder geval in absolute zin groter wordt.

\section{Conclusies en verder onderzoek}

Samenwerking tussen bedrijven in de vorm van supply chain management biedt mogelijkheden om kosten te besparen en/of service aan de eindklant van de supply chain te verbeteren. Vaak heeft SCM betrekking op het uitwisselen van meer informatie, het herverdelen van activiteiten en investeringen en het overhevelen van beslissingsbevoegdheden. Bovendien blijven verbeteringen die echt goed werken vaak niet exclusief voor de bedenkers. Door deze kenmerken van SCM kunnen er situaties optreden waar een vorm van SCM bedrijfseconomisch aantrekkelijk is voor de keten als geheel en voor sommige partijen in die keten, maar erg onaantrekkelijk voor sommige andere partijen in die keten.

De voorgaande discussie leidt tot een aantal onderzoeksvragen. Ten eerste, in welke situaties zijn de potentiële belemmeringen voor samenwerking écht een probleem en welke vormen van SCM kunnen dan wél worden geïmplementeerd? Zo zal informatie-uitwisseling over kosten vaak problematisch zijn, maar niet altijd. Waar hangt dat vanaf? Wat betekent dit voor de inrichting van SCM? Dergelijke vragen kunnen bijvoorbeeld worden geanalyseerd met speltheorie, transactiekostentheorie of principal/agencytheorie. Maar ook sociologische benaderingen waarin de rol van vertrouwen aan de orde komt zijn van belang (Zaheer en Venkatrman, 1995). Het zou interessant zijn om empirisch vast te stellen welke belemmeringen bedrijven het meest relevant vinden. Waar hangt dat vanaf en welke oplossingen gebruikt men om samenwerking mogelijk te maken (of waarom vindt men geen oplossingen)?

Ten tweede zou onderzocht kunnen worden welke veranderingen daadwerkelijk plaatsvinden in systemen voor de analyse van kosten en voor prestatiemeting wanneer bedrijven SCM invoeren. Welke veranderingen treden op en waar hangen deze vanaf? Is dit afhankelijk van verschillende vormen van SCM?

Ten derde zou geïnventariseerd kunnen worden wat de meest vooroplopende praktijkervaringen zijn met de ontwikkeling en invoering van nieuwe systemen voor de analyse van kosten en voor prestatiemeting. Hoe worden kosten geanalyseerd over verschillende schakels in de keten? Hoe wordt kosteninformatie uitgewisseld bij productontwikkeling?

SCM is een relevant onderzoeksterrein voor management accounting. In dit artikel is SCM vanuit de operations management-literatuur beschreven. In die literatuur wordt met name een verbetering van de totale supply chain onderzocht. Maar supply chains worden bestuurd door meerdere beslissers, met verschillende belangen en verschillende informatie. In de operations management-literatuur ontstaat nu ook steeds meer aandacht voor gedecentraliseerde situaties met meerdere beslissers (Cachon, 1999). Hoewel het vakgebied management accounting zich meestal richt op beheersingsproblemen in een hiërarchische context, kan het onderzoek ook goed worden gericht op de beheersingsproblemen bij horizontale relaties tussen partijen in een supply chain. Verder is SCM een onderzoeksveld waar onderzoekers van management accounting 
vruchtbaar kunnen samenwerken met onderzoekers van andere disciplines (Wouters en Van Donselaar, 1999, beschrijven een voorbeeld van dergelijke samenwerking).

\section{I T E R A T U U R}

Abrahamsson, M. en S. Brege, (1997), Structural changes in the supply chain, The International Journal of Logistics Management 8 (1): pp. 35-44.

Aken, J.E. van, (1973), Enige micro-economische beschouwingen over conjunctuur, Maandblad voor Bedriffsadministratie en Organisatie (77): pp. 88-94.

Anderson, E., G.S. Day en V.K. Rangan, (1997), Strategic channel design, Sloan Management Review (Summer): pp. 59-69.

Beamon, B., (1999), Measuring supply chain performance, International Journal of Operations and Production Management 19 (3): pp. 275-292

Bechtel, C. en J. Jayaram, (1997), Supply chain management: a strategic perspective, International Journal of Logistics Management (8) 1: pp. 15-34

Berglund, M. P. van Laarhoven, G. Sharman, en S. Wandel, (1999), Whither third-party logistics? zal verschijnen in International Journal of Logistics Management.

Bourland, K.E., S.G. Powell en D.F. Pyke, (1996), Exploiting timely demand information to reduce inventories, European Journal of Operational Research (92): pp. 239-253

Breejen, R. den en E.W. Foekens, (1997), EDI als marketinginstrument, Maandblad voor Accountancy en Bedriffseconomie (71): pp. 88-94

Burnes, B., en S. New, (1996), Strategic advantage and supply chain collaboration. A. T. Kearny and Institute of Logistics, London

Buzzel, R.D. en G. Ortmeyer, (1995), Channel partnerships streamline distribution, Sloan Management Review (Spring) pp. 85-96.

Cachon, G.P., (1999), Competitive supply chain inventory management, in: Quantitative models for supply chain management, Tayur S., R. Ganeshan en M. Magazine (Editors), Kluwer Academic Publishers.

Carr, L. P. en C. D. Ittner, (1992), Measuring the cost of ownership, Journal of Cost Management 6 (3): pp. 42-51.

Cavinato, J.L., (1991), Identifying interfirm total cost advantages for supply chain competitiveness, International Journal of Purchasing and Materials Management (Fall): pp. 10-15

Cooper, M.C., D. M. Lambert en J.D. Pagh, (1997), Supply chain management: more than a new name for logistics, The International Journal of Logistics Management 8 (1): pp. 1-13.
Cooper, R. and T. Yoshikawa, (1994), Inter-organizational cost management systems: The case of Tokyo-YokohamaKamakura supplier chain, International Journal of Production Economics (37): pp. 51-62.

Davis, T., (1993), Effective supply chain management, Sloan Management Review, (Summer): pp. 35-46.

Donselaar, K.H. van, L. Kopczak, en M. Wouters, (1999), The use of advance demand information in a project-based supply chain, zal verschijnen in European Journal of Operational Research

Ellram, L. M., (1995), Activity-based costing and total cost of ownership: a critical linkage, Journal of Cost Management 8 (4): pp. 22-30

Feitzinger, E. en H.L. Lee, (1997), Mass customization at Hewlett-Packard: the power of postponement, Harvard Busıness Review (Januari-February): pp. 116-123.

Fisher, M L., J.H. Hammond, W.R. Obermeyer en A. Raman, (1994), Making supply meet demand in an uncertain world, Harvard Business Review (May-June): pp. 83-93.

Forrester, J.W., (1961) Industrial Dynamics, MIT Press, Cambridge, USA

Frances, J., and E. Carnsey, (1996), Supermarkets and suppliers in the United Kingdom: system integration, information and control, Accounting, Organizations and Society 21: pp. 591610.

Gietzmann, M.B., (1996), Incomplete contracts and the make or buy decision: Governance design and attainable flexibility, Accounting, Organizations and Society 21: pp. 611-626.

Gietzmann, M B. en J.G. Larsen, (1998), Motivating subcontractors to perform development and design tasks, Management Accounting Research 9: pp. 285-309.

Hobbs, J.E., (1996), A transaction cost approach to supply chain management, Supply Chain Management 1 (2): pp. 15-27.

Hoek, R. van, (1998), Reconfiguring the supply chain to implement postponed manufacturing, International Journal of Logistics Management 9 (1): pp. 95-110.

Holmström, J., (1997), Product range management: a case study of supply chain operations in the European grocery industry, Supply Chain Management 2 (3): pp. 107-115.

Holmström, J., (1998), Business process innovation in the supply chain - a case study of implementing vendor managed inventory, European Journal of Purchasing \& Supply Management 4: pp. 127-131.

Hopwood, A.G., (1996), Looking across rather than up and down: on the need to explore the lateral processing of information, Accounting, Organizations and Society 21: pp. $589-590$.

Ittner, C.D. en D.F. Larcker, V. Nagar en M.V. Rajan, (1997), Supplier selection, monitoring practices, and firm performance, paper gepresenteerd op de Management Accounting Conference of the American Accounting Association, Memphis TN, 1997. 
Kok, A.G. de, (1990), Hierarchical production planning for consumer goods, European Journal of Operational Research 45: pp. 55-69.

Kurt Salmon Associates, Inc., (1993), Efficient Consumer Response - Enhancing consumer value in the grocery industry, Washington, D.C.: Food Marketing Institute.

Lalonde, B.J. en T.L. Pohlen, (1996), Issues in supply chain costing. The International Journal of Logistics Management 7 (1): pp. 1-12.

Lee, $H$. en C. Billington, (1992), Managing supply chain inventory: Pitfalls and opportunities, Sloan Management Review (Spring): pp. 65-73

Lee, H., V. Padmanabhan en S. Whang, (1997), The bullwhip effect in supply chains, Sloan Management Review 38 (3): pp. 93-102.

Narayanan, V.R. en A. Raman, (1998), Reducing Agency Costs in a Supply Chain by Contracting on Retail Inventory, Working paper, Harvard Business School, Cambridge.

New, S.J., (1996), A framework for analysing supply chain improvement, International Journal of Operations \& Production Management 16 (4): pp. 19-34.

New. S.J., (1997), The scope of supply chain management research, Supply Chain Management 2 (1): pp. 15-22.

Radhakrishnan, S. en B. Srinidhi, (1997), Information Exchange in a Value Chain: Implications for Pricing and Profitability. Paper presented at the Management Accounting Conference of the American Accounting Association, Memphis TN, 1997.

Roodhooft, F. en J. Konings, (1996), Vendor selection and evaluation, an activity based costing approach, European Journal of Operational Research 96: pp. 97-102.

Shank, J. en V. Govindarajan, (1992), Strategic cost management: the value chain perspective, Journal of Management Accounting Research 4: pp. 179-197.

Tsay, Andy A., Steven Nahmias en Narendra Agrawel, (1999), Modeling supply chain contracts: a review, in: Quantitative models for supply chain management, S. Tayur, R. Ganeshan en M. Magazine (Editors), Kluwer Academic Publishers.
Vlist, P. van der, J.E.M. Hoppenbrouwers en H.M. Hegge, (1998), Extending the enterprise through multi-level supply control, International Journal of Production Economics 53 (1): pp. 35-42.

Wortmann, J.C., (1994), Meer niveau-afstemming in industriële toelevering, Bedriffskunde 66 (4): pp. 24-30.

Wouters, M., (1999), Betere kosteninformatie, uitgebreidere prestatiemeting, en de verdeling van kosten en opbrengsten, Inkoop \& Logistiek, bijlage bij nr. 6: X-XVI.

Wouters, M., G. Sharman en J.C. Wortmann, (1999), Reconstructing the sales and fulfillment cycle to create supply chain differentiation, zal verschijnen in International Journal of Logistics Management.

Wouters, M. en K. van Donselaar, (1999), Design of operations management internships across organizations - Teaching $O M$ by doing $O M$, zal verschijnen in Interfaces.

Zaheer, A. en N. Venkatraman, (1995), Relational governance as an interorganizational strategy: an empirical test of the role of trust in economic exchange, Strategic Management Journal 16: pp. 373-392.

\section{NOTEN}

1 Administratieve processen van bestellen, bevestigen en factureren kunnen geautomatiseerd en efficiënter worden uitgevoerd met behulp van Electronic Data Interchange (EDI). Informatiesystemen genereren bestellingen (of besteladviezen die kunnen worden gewijzigd) en het is uiterst efficiënt als deze bestellingen elektronisch kunnen worden verzonden naar de leverancier, waar deze direct in de systemen worden verwerkt (in vergelijking met een bestelling maken op grond van een computerprint, deze faxen naar de leverancier, die de bestelling dan weer in een informatiesysteem invoert). Ook bevestigingen, vrachtbrieven, ontvangstbevestigingen, en facturen kunnen op deze wijze worden geautomatiseerd (Van den Breejen en Foekens, 1997). 